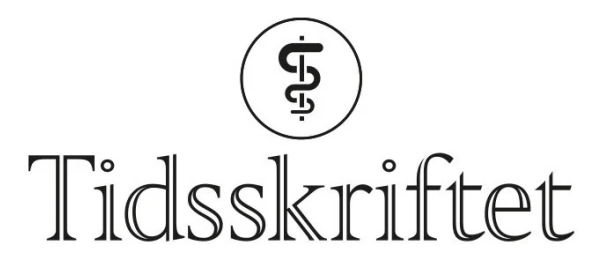

DEN NORSKE LEGEFORENING

\title{
La tallene få tale
}

DEBATT

\section{EILIV LUND}

eluooo@post.uit.no

Eiliv Lund er lege ved Kreftregisteret og professor emeritus i epidemiologi ved Institutt for samfunnsmedisin, Universitetet i Troms $\varnothing$ - Norges arktiske universitet. Han arbeidet som spesiallege i epidemiologi i Helsedirektoratet under starten av hivepidemien.

Forfatteren har fylt ut ICMJE-skjemaet og oppgir ingen interessekonflikter.

\section{Norsk offentlighet har vært for opptatt av antall døde under koronapandemien.}

Epidemier har alltid eksistert. På 16oo-tallet var det i London alvorlige koleraepidemier. For å følge med på de mange epidemiene ga kongen i 1603 prestene beskjed om å telle antall fødte og døde. Antall døde ble samlet hver uke i Londons Bills of mortality (1). I 1662 utga John Graunt en bok der han viste at det var nødvendig å bruke populasjonstenkning og gruppeanalyser for å kunne beskrive epidemiene. Dette ga støtet til populasjonsbasert statistikk. Myndighetene kunne ikke bare lenger oppgi et ubearbeidet tall over antall døde. Graunt ble dermed grunnleggeren av moderne epidemiologi som grunnlag for samfunnsmedisin.

\section{Daglige rapporter}

Fra koronaepidemien kom til Norge, ble helsemyndighetenes opplysninger om dens fremmarsj i alt vesentlig gitt av Folkehelseinstituttet (FHI) i form av daglige covid-19dagsrapporter (2).

Fra begynnelsen av inneholdt dagsrapportene få opplysninger. Hovedoppmerksomheten var hele tiden rettet mot antall døde gitt uten alder og kjønn. Dette tallet utgjorde hovedinformasjonen til befolkningen. Det ble gitt som nye tilfeller hver dag og som kumulert antall. Alle mediene brakte dette daglig, og det ble repetert på pressekonferanser. Dette tallet er et rått og ujustert tall uten henvisning til befolkningens sammensetning.

Dernest fulgte en tabell med smittede etter alder. Den viste smittede delt inn i tiårsaldersgrupper helt ned i barneårene. Her så man en ganske jevn fordeling etter aldersgrupper, med flest yngre kvinner testet. Selv små barn testet positivt. Videre ble antall testede publisert, men uten nærmere inndelinger i kjønn og alder. Grunnlaget for å ta prøver skiftet underveis i pandemiforløpet, så de representerte aldri tilstanden i befolkningen. 
Tallet av døde danner grunnlaget for å beregne en ujustert letalitet (case fatality rate), dvs. hvor mange av de smittede som overlever. Raten i Norge har hele tiden ligget blant de laveste i Europa, som uttrykk for effektiv behandling - uten at dette ble fremhevet positivt. Kan årsaken tilskrives vårt sosialdemokratiske helsevesen, som alle har fri adgang til og som har hindret unødvendig bruk av antibiotika?

\title{
Mer raffinerte rapporter
}

Publiseringen av «tallet» fortsatte frem til 15. april, da Folkehelseinstituttet begynte å publisere døde etter alder og kjønn. Da ble det mulig å beregne letalitet etter alder, og man så at det ikke var noen døde under 50 år. I aldersgruppen 50-69 var det $13 \mathrm{~d} \varnothing \mathrm{de}$, og blant de eldre var det $118 \mathrm{~d} ø \mathrm{dsfall}$. Dette var essensiell informasjon for å vurdere alvorligheten av pandemien og dens dynamikk.

«Tallet» preget også sammenligningene med andre land. I lengre tid ble det gitt sammenligninger mellom land basert på disse antall døde. Etter hvert kom letalitet og så dødelighet i forhold til befolkningen, ujustert. I alle andre epidemiologiske analyser benyttes det alltid alders- og kjønnsspesifikke rater for å lage en standardisert sammenligning. Slik eksisterer knapt i litteraturen om koronapandemien.

\author{
«Sammen med bilder fra Wuhan og Italia synes det å ha skjedd en \\ analog feilslutning om at samme tsunami eller katastrofe ville ramme \\ oss»
}

Betydningen av sårbare grupper blir med slike presentasjoner av tallene helt fraværende. Folkehelseinstituttet ga først fra medio april opplysninger om hvor stor prosentandel som døde i sykehjem. Den lå på $60 \%(\underline{2})$. Alder og kjønn blir fremdeles ikke gitt. I Norge er det omtrent 40 ooo innlagte i sykehjem (tall fra Statistisk sentralbyrå) (3). Om lag 6o \% eller 150 av totalt 250 dødsfall i Norge har funnet sted der (2). Enkle beregninger viser at beboere på sykehjem har en relativ risiko for å dø på ca. 200 i forhold til resten av befolkningen. Helsedirektøren har beklaget det høye tallet på døde i enkelte sykehjem. Tilsvarende tall er kjent fra England, der det er beregnet at ca. 20 ooo er døde i sykehjem (4.). I Sverige beklaget myndighetene tidlig at de hadde mislyktes i å beskytte de eldste. Både i Norge (5) og England (므) har det blitt pekt på manglende utstyr for testing og smittekontroll.

\section{Burde analysert tidligere}

Det kan se ut til at det begynner å gå opp for helsepersonell at de har glemt både John Graunt og andre deler av lærdommen fra public health. I en pågående diskusjon på lederplass i The British Medical Journal fremkommer det en stor grad av bekymring over de siste tiårenes nedbygging av offentlig helsevesen og tilhørende spesialiteter som epidemibekjempelse (7.).

Norsk offentlighet har vært opptatt av tallet på døde uten å informere om det spesielle dødelighetsmønsteret, den gode overlevelsen og betydningen av risikofaktorer samt den svake storbyurbaniseringen. Sammen med bilder fra Wuhan og Italia synes det å ha skjedd en analog feilslutning om at samme tsunami eller katastrofe ville ramme oss. Om det var nødvendig å skape angst for å få folk til å følge retningslinjene i starten, vil forbli ubesvart. Men en grundig epidemianalyse tidlig i forløpet ville ha vist at det som skjedde i Italia og en del andre europeiske land, hadde ikke vi behøvd å frykte i Norge. 
1. Morabia A. Epidemiology's 35oth Anniversary: 1662-2012. Epidemiology 2013; 24: 179-83. [PubMed] [CrossRef]

2. Folkehelseinstituttet. COVID-19. Dagsrapport 15.4.2020.

https://www.fhi.no/contentassets/e1106o7a67df46cbba8e3oa443264a73/vedlegg/2020.04.15-dagsrapport-covid-19.pdf Lest 9.8.2020.

3. Statistisk sentralbyrå. Sjukeheimar, heimetenester og andre omsorgstenester. https://www.ssb.no/helse/statistikker/pleie Lest 9.8.2020.

4. Burki T. England and Wales see 20 ooo excess deaths in care homes. Lancet 2020; 395: 1602. [PubMed][CrossRef]

5. Hordnes K, Løland KK, Bovim E. Asymptomatiske smittebærere av sars-CoV-2 i sykehjem. Tidsskr Nor Legeforen 2020; 140. doi: 10.4045/tidsskr.20.0316. [PubMed][CrossRef]

6. McKee M, Gill M, Wollaston S. Public inquiry into UK's response to covid-19. BMJ 2020;369: m2052. [PubMed][CrossRef]

7. Godlee F. Covid-19: Testing testing. BMJ 2020;369: m1918. [CrossRef]

Publisert: 18. august 2020. Tidsskr Nor Legeforen. DOI: 10.4045/tidsskr.20.0490

Mottatt 1.6.2020, første revisjon innsendt 27.6.2020, godkjent 9.8.2020.

(C) Tidsskrift for Den norske legeforening 2023. Lastet ned fra tidsskriftet.no 26. april 2023. 